Weed Science

www.cambridge.org/wsc

\section{Review}

Cite this article: Ahn E, Prom LK, Magill C (2021) Diseases of Johnsongrass (Sorghum halepense): possible role as a reservoir of pathogens affecting other plants. Weed Sci. 69: 393-403. doi: 10.1017/wsc.2021.31

Received: 11 November 2020

Revised: 5 March 2021

Accepted: 5 April 2021

First published online: 19 April 2021

\section{Associate Editor:}

Chenxi Wu, Bayer U.S. - Crop Science

\section{Keywords:}

Cross infection; plant pathogens; weed.

\section{Author for correspondence:}

Ezekiel Ahn, Department of Plant Pathology \& Microbiology, Texas A\&M University, 496 Olsen Boulevard, College Station, TX 77840.

(Email: eja85@tamu.edu)

\title{
Diseases of Johnsongrass (Sorghum halepense): possible role as a reservoir of pathogens affecting other plants
}

\section{Ezekiel Ahn ${ }^{1}(1)$, Louis K. Prom ${ }^{2}$ (1) and Clint Magill ${ }^{3}$ (1)}

${ }_{1}^{1}$ Postdoctoral Research Associate, Department of Plant Pathology \& Microbiology, Texas A\&M University, College Station, TX, USA; ${ }^{2}$ Research Plant Pathologist, USDA-ARS Southern Plains Agricultural Research Center, College Station, TX, USA and ${ }^{3}$ Professor, Department of Plant Pathology \& Microbiology, Texas A\&M University, College Station, TX, USA

\begin{abstract}
Johnsongrass [Sorghum halepense (L.) Pers.] is one of the most noxious weeds distributed around the world. Due to its rapid growth, wide dissemination, seeds that can germinate after years in the soil, and ability to spread via rhizomes, S. halepense is difficult to control. From a perspective of plant pathology, S. halepense is also a potential reservoir of pathogens that can eventually jump to other crops, especially corn (Zea mays L.) and sorghum [Sorghum bicolor (L.) Moench]. As one of the most problematic weeds, S. halepense and its diseases can provide useful information concerning its role in diseases of agronomically important crops. An alternative consideration is that $S$. halepense may provide a source of genes for resistance to pathogens. While some studies have verified that pathogens isolated from $S$. halepense actually cause disease on host crops through cross inoculation, similarity of disease symptoms and pathogen morphology have been used for identity of the disease agent in most studies. Availability of DNA sequence information has greatly altered and improved pathogen identification, leading to significant changes in phylogenetic assignments. Reclassification of pathogens, especially fungi, raises new questions concerning the role of $S$. halepense as a disease reservoir. Our goals in this review are to pinpoint, where possible, diseases for which $S$. halepense acts as a significant pathogen reservoir and to point out problem areas where further research is needed.
\end{abstract}

\section{Sorghum halepense and Diseases}

Invasive plant species often dominate native species in competition (Schwinning et al. 2017). Among invasive plant species, Johnsongrass [Sorghum halepense (L.) Pers.], a wild relative of sorghum [Sorghum bicolor (L.) Moench], is known as an aggressive invader of natural or minimally managed habitats (Sezen et al. 2016).

After its introduction from the Mediterranean area into the United States in the 1800s, $S$. halepense was disseminated rapidly. By the late nineteenth century, its presence was almost nationwide, and its pernicious nature led to the first federal appropriation specifically for weed control in 1900 (McWhorter 1971).

By competing for resources, through allelopathy, and by serving as a host for crop pests, S. halepense can greatly diminish crop yield (Soti et al. 2020); for example, heavy infestations of S. halepense reduced the yield of soybean [Glycine max (L.) Merr.] in Mississippi 23\% to 42\% (McWhorter and Hartwig 1972). While it is generally considered a problem in corn (Zea mays L.), cotton (Gossypium hirsutum L.), and sugarcane (Saccharum officinarum L.) in tropical to temperate climates, 53 countries had reported it as a weed in 30 different crops by 1983 (Warwick and Black 1983). Furthermore, in the United States, tens of millions of dollars are attributed annually to management costs and yield losses (Burke et al. 2006).

Other concerns associated with $S$. halepense include the fact that weeds may be obligate alternate hosts for some pathogens, and herbicides used for weed control may interact with plant pathogens that might lead to a modified gene pool (Wisler and Norris 2005). Although S. halepense has been extensively studied in terms of its invasive properties and to discover potential methods of control, details about its diseases and potential roles as an alternate host for pathogens of major crops are lacking. We feel this review will be of interest to weed scientists, as it points out problems with earlier studies, especially as related to identification of species of pathogens, and the need and means that can be used to verify cross infection.

Sorghum halepense has been shown to serve as an alternative host for several insect pests of sorghum and corn, including sorghum midge [Contarinia sorghicola (Coquillett) (Diptera)], a leafhopper [Graminella nigrifrons (Forbes) (Homoptera)], and a corn leaf aphid [Rhopalosiphum maidis (Fitch) (Homoptera)] (Warwick and Black 1983), and many of the insects harbored in $S$. halepense may serve as vectors for diseases of crops such as maize chlorotic 
Table 1. List of fungal and oomycete pathogens found in Sorghum halepense, common hosts, and common names or symptoms of diseases.

\begin{tabular}{|c|c|c|c|}
\hline Pathogen found in S. halepense & Common host(s) & Name of disease or common symptom & Original reference \\
\hline \multicolumn{4}{|l|}{ Fungi } \\
\hline \multicolumn{4}{|l|}{ Ascomycota } \\
\hline Bipolaris cynodontis ${ }^{\mathrm{a}}$ & Bermudagrass ${ }^{a}$ & Leaf spot & Pratt (2006) \\
\hline \multicolumn{4}{|l|}{ Bipolaris spicifera ${ }^{\mathrm{a}}$} \\
\hline Bipolaris halepense & S. halepense & Leaf spot & Chiang et al. (1989a) \\
\hline Bipolaris sorghicola & Arabidopsis, barley, onion, sorghum & Target leaf spot & Acciaresi and Mónaco (1999) \\
\hline Claviceps africana & Sorghum & Ergot & Velasquez-Valle et al. (1998) \\
\hline Colletotrichum sublineola ${ }^{a}$ & Sorghum ${ }^{a}$ & Anthracnose & Xavier et al. (2018) \\
\hline Curvularia lunata & Corn, rice, sorghum, and more & $\begin{array}{l}\text { Leaf spot } \\
\text { Grain mold }\end{array}$ & Pratt (2006) \\
\hline Curvularia geniculata & Corn & Leaf spot & Pratt (2006) \\
\hline Exserohilum rostratum ${ }^{a}$ & Bottle gourd, Pineapple, Rice, Bermudagrass ${ }^{a}$ & Leaf spot & Pratt (2006) \\
\hline Exserohilum turcicum ${ }^{\mathrm{a}}$ & Corn, sorghum & Northern corn leaf blight & Chiang et al. (1989b) \\
\hline Gloeocercospora sorghia & Sorghum & Zonate leaf spot & Chiang et al. (1989c) \\
\hline Macrophomina phaseolina & $\begin{array}{l}\text { Very wide host range } \\
\text { cotton, sorghum, beans, etc. }\end{array}$ & Charcoal stalk rot, root rot & Khan (2007) \\
\hline \multicolumn{4}{|l|}{ Basidiomycota } \\
\hline Rhizoctonia solani ${ }^{b}$ & $\begin{array}{l}\text { Turfgrass, soybean, }{ }^{b} \text { potato, rice, corn, } \\
\text { sorghum }\end{array}$ & $\begin{array}{l}\text { Brown patch, damping off, black scurf, } \\
\text { root rot, stem rot, sheath blight of rice }\end{array}$ & Demirci and Eken (1999) \\
\hline Rhizoctonia zeae & Turfgrass, corn & Brown patch, leaf spot & Demirci and Eken (1999) \\
\hline $\begin{array}{l}\text { Sporisorium cruentum } \\
\text { (Sphacelotheca holci) }^{\mathrm{a}}\end{array}$ & Sorghum ${ }^{a}$ & Loose kernel smut & Massion and Lindow (1986) \\
\hline \multicolumn{4}{|l|}{ Oomycetes } \\
\hline Peronoscleospora sorghi & Sorghum & Downy mildew & Amador et al. (1974) \\
\hline
\end{tabular}

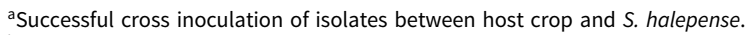

${ }^{\mathrm{b}}$ Transfer onto $\mathrm{S}$. halepense with an isolate from the host crop.

Table 2. List of bacterial pathogens found in Sorghum halepense, common hosts, and common name or symptoms of diseases.

\begin{tabular}{|c|c|c|c|}
\hline Pathogen found in S. halepense & Common host(s) & Name of disease or common symptom & Original reference \\
\hline \multicolumn{4}{|l|}{ Bacteria } \\
\hline Clavibacter michiganensis $^{\mathrm{a}}$ & Corn, ${ }^{a}$ sugarcane, sorghum & Goss's wilt & Ikley et al. (2015) \\
\hline Pseudomonas syringae & Wide range of monocots and dicots & Bacterial leaf spot & Mikulas and Sule (1979). \\
\hline Rickettsia-like bacteria & Peach & Phony disease & Weaver et al. (1980) \\
\hline Xanthomonas vasicola ${ }^{b}$ & Corn $^{b}$ & Bacterial leaf streak & Hartman (2018) \\
\hline Xylella fastidiosa ${ }^{\mathrm{b}}$ & Grape, ${ }^{\text {b }}$ olive (Olea europaea L.) & Pierce's disease & Turner and Pollard (1959) \\
\hline
\end{tabular}

a Successful cross inoculation of isolates between host crop and S. halepense.

${ }^{\mathrm{b}}$ Transfer onto $S$. halepense with an isolate from the host crop.

Table 3. List of viral pathogens found in Sorghum halepense, common hosts, and common name or symptoms of diseases.

\begin{tabular}{llll}
\hline Pathogen found in S. halepense & Common host(s) & Name of disease or common symptom & Original reference \\
\hline Viruses & & & \\
S. halepense mosaic virus & Corn, sorghum & Chlorosis, stunting, mottling & Stewart et al. (2017) \\
Maize chlorotic dwarf virus & Corn, sorghum & Chlorosis, stunting, mottling & Stewart et al. (2014) \\
Maize dwarf mosaic virus & Corn, sorghum & Chlorosis, stunting, mottling & Stewart et al. (2014) \\
Sugarcane mosaic virus & Corn, sorghum & Chlorosis, stunting, mottling & Mohammadi et al. (2006) \\
\hline
\end{tabular}

dwarf virus (MCDV) and maize dwarf mosaic virus (MDMV) (King and Hagood 2003). However, in this review, we excluded information regarding insect pests other than those known to transmit viruses. Tables $1-3$ summarize fungal, bacterial, and viral pathogens, respectively, that have been observed and verified to infect $S$. halepense and list other common hosts and common names of diseases caused by those pathogens.

\section{Fungal Diseases of Sorghum halepense}

Compared with other classes of pathogens, many fungi have been reported as pathogens of $S$. halepense. While sometimes mentioned as potential biocontrol organisms, their presence usually identifies $S$. halepense as a potential alternate host to a non-weed species.
Here we will first consider fungi, especially ascomycetes, known to have a wide host range, and then consider those that exhibit a high degree of host specificity.

\section{Ascomycota}

\section{Macrophomina phaseolina}

An example of a pathogen with a very wide host range is Macrophomina phaseolina (Tassi) Goid. Macrophomina phaseolina has no known sexual stage. However, it is classed as an ascomycete based on the presence of DNA sequences for mating-type alleles (Nagel et al. 2018). It has been identified as the cause of charcoal rots in stem infections and damping off when roots are compromised for more than 500 wild and cultivated hosts, 
including S. halepense (Khan 2007). Macrophomina phaseolina is widely present in soil and has been reported to cause yield losses of $30 \%$ to $50 \%$ in southern soybean production regions of the United States (McGee 1992; Yang and Navi 2005). In sorghum, up to $46.6 \%$ yield loss was recorded for susceptible plants with complete wilting and lodging (Arora and Dhurwe 2014). In a study in Australia, M. phaseolina has been isolated from the roots of symptomless plants of 23 weed species, including $S$. halepense (Fuhlbohm et al. 2012). In a recent study of genetic diversity of M. phaseolina in Senegal based on DNA sequences of five loci, internal transcribed spacer (ITS), translation elongation factor (TEF), actin (ACT), calmodulin (CAL), and tubulin (TUB), two clades were generated, but no consistent correlation was found among genotype, host, or geographic location, and isolates from both clades could even occur on the same host at the same location (Sarr et al. 2014). Another recent study suggested that five Macrophomina species can be defined based on DNA sequence diversity among isolates collected from oilseed crops in Brazil (Machado et al. 2019). However, no indications for host specificity were described. Thus, while $S$. halepense could serve as a source of inoculum on occasion, it seems unlikely that it has a large impact on the overall spread of the crop diseases caused by Macrophomina.

\section{Curvularia spp. and Bipolaris spp.}

Curvularia lunata (Wakker) Boedijn and Curvularia geniculata (Tracy \& Earle) Boedijn have been isolated from typical leaf spot lesions of a wide range of hosts, including S. halepense (Pratt 2006). No clear indication of host specificity has been seen. In a test to examine host range, single spore cultures of $C$. lunata isolated from lesions of the pulse black gram [Vigna mungo (L.) Hepper] were grown and used to prepare high concentrations of inoculum (Lal et al. 2013). When sprayed onto 30-d-old plants of 58 plant species in seven families, other than for the only three Euphorbuaceae species tested, at least one species in the other six families developed leaf spot symptoms. While S. halepense was not tested, corn and rice (Oryza sativa L.) were positive, but Sorghum vulgare (a synonym of S. bicolor) was negative (Lal et al. 2013). In other cases, C. lunata has been shown to cause leaf spot disease on grain sorghum in Pakistan (Akram et al. 2014) and on sweet sorghum in China (Tong et al. 2016), both of which are $S$. bicolor. Curvularia lunata is also often identified as a cause of grain mold in sorghum (Bandyopadhyay et al. 1991; Prom et al. 2017b). In corn, C. lunata is reported to cause approximately $10 \%$ to $60 \%$ yield losses and up to $33.4 \%$ losses in grain yield under hot and humid conditions (Bisht et al. 2018; DingFa et al. 1999).

Curvularia geniculata also causes leaf spot on corn and has previously been isolated from $S$. halepense (Hodges and Madsen 1979). Moreover, C. lunata and C. geniculata are associated with leaf spots of Lacatan banana (Musa acuminata Colla) plants (Meredith 1963). In a recent study, C. geniculata was confirmed as the principal alfalfa (Medicago sativa L.) foliar pathogen in the Brazilian state of Rio Grande do Sul (Ávila et al. 2017). Based on a survey conducted of seed-borne fungal diseases of rice in Burkina Faso, incidence rate of C. geniculata was $0.5 \%$ to $2 \%$ (Ouedraogo et al. 2016).

Bipolaris halepense Chiang, Leonard \& Van Dyke was isolated from diseased leaves of $S$. halepense in North Carolina in 1989 (Chiang et al. 1989a). Conidia of $B$. halepense resemble those of Bipolaris maydis (Y. Nisik. \& C. Miyake) Shoemaker, a foliar pathogen of corn, but $B$. halepense is only weakly pathogenic to corn and did not mate with fertile isolates of either mating type of $B$. maydis (Chiang et al. 1989a). Symptoms from B. halepense when found on $S$. halepense lack the zonate pattern, so are more typical for the lesions caused by Bipolaris sorghicola (Lefebre \& Scherwin) Alcorn (Manamgoda et al. 2014). B. sorghicola was found on $S$. halepense in La Plata, Argentina, and the diseased $S$. halepense plants were described as having leaf spots (Acciaresi and Mónaco 1999). Katewa et al. (2006) inoculated conidia of $B$. sorghicola to sorghum cultivars 'IS164' and 'SU 45', and the reduction in grain yields was near $50 \%$ in both cultivars compared with the control.

Bipolaris sorghicola is reported to cause target leaf spot on barley (Hordeum vulgare L.), onion (Allium cepa L.), Arabidopsis thaliana spp., and sorghum (Peng et al. 2016).

In a 2006 report by Pratt, besides C. lunata, and C. geniculata, Bipolaris cynodontis (Marig.) Shoemaker, Bipolaris spicifera (Banier) Subr, and Exserohilum rostratum (Drechs.) Leonard \& Suggs (formerly Bipolaris halodes) were also recovered from symptomatic leaves of $S$. halepense. In this case, the $S$. halepense was growing in association with Bermudagrass [Cynodon dactylon (L.) Pers.]. Spores produced from cultures of the two Bipolaris species and E. rostatum were cross-infective to Bermudagrass, causing typical leaf spot symptoms (Brecht et al. 2007; Pratt 2006). Bipolaris cynodontis has also been isolated from rice (Zehhar et al. 2008). In Bangladesh, the major pathogen of leaf blight in wheat (Triticum aestivum L.) is Bipolaris sorokiniana (Sacc.) Shoemaker, but other fungal species such as Bipolaris cynodontis (Marig.) Shoemaker, Bipolaris oryzae (Breda De Haan) Shoemaker, Bipolaris tetramera (Mckinney) Shoemaker, and Bipolaris victoriae (Meehan \& Murphy) Shoemaker have been also isolated from infected wheat leaves (Momtaz et al. 2019). Although it is not proven to cause severe disease, B. cynodontis was found in $10.4 \%$ of the rice seed lots from a total of 722 rice seed lots in Rio Grande do Sul, Brazil (Meneses et al.2014). As in the case of Macrophomina, even if S. halepense is a host for these pathogens, based on their extensive host ranges, it seems unlikely that it regularly serves as a major source of inoculum for this group of pathogens.

It is important to note that C. lunata refers to the asexually reproducing form (anamorph) of an ascomycetous fungus that also has a sexually reproducing form (teleomorph) in the genus Cochliobolus. Because identification of Curvularia based primarily on conidial morphology is not highly discriminatory, efforts are being made to use DNA sequence information to sort out the phylogeny of the group. Index Fungorum (http://www.indexfungorum.org/ Names/Names.asp) lists 134 species of Bipolaris, 217 species of Curvularia, and 54 species of Cochliobolus, including C. lunatus, the presumed teleomorph of C. lunata. Several teleomorphs such as Cochliobolus heterostrophus (Drechsler) Drechsler are associated with serious diseases of specific hosts, including southern leaf blight of corn. When sequences of ribosomal ITS and a portion of the single-copy gene $g 3 p d$ (glyceraldehyde-3-phosphate dehydrogenase, including 2 introns) for 41 species defined as Cochliobolus were subjected to phylogenetic analysis, the results grouped the isolates into two clusters (Berbee et al. 1999). For 16 species in cluster 2, the classification, if based on asexual spores, would be either Curvularia or Bipolaris. All species in cluster 1 (14 Cochliobolus species) were associated with Bipolaris as the anamorph. Addition of TEF and the large-subunit rRNA (LSU) sequences led to further reclassification of morphologically defined species of Curvularia and Bipolaris (Manamgoda 2015). In these studies, isolates from sorghum were classified into seven different species, none of which was C. lunata (Manamgoda 2015; Marin-Felix et al. 2020). Clearly, it will be important to use DNA sequence information to 
identify the species and to perform cross-species inoculation tests to determine whether Curvularia from S. halepense is a threat to neighboring crop species. The similarity of Curvularia and Bipolaris was not surprising, as each is known to derive from teleoforms of Cochliobolus. However, these observations show that isolates from different hosts described as separate species of Curvularia or Bipolaris in earlier literature may not meet today's species definitions. It is also possible that some are anamorphs derived from genetically distinct species that do have host specificity. (At one time these fungi were all classed as members of the genus Helminthosporium and later Drechslera.)

\section{Exserohilum spp.}

Exserohilum rostratum (or Setosphaeria rostatum when the name for the sexual stage is used), as stated previously, has been isolated from $S$. halepense and also appears to have a very wide host range. When E. rostratum isolates from banana were tested via assays using detached leaves from 128 different plant species belonging to 47 families, 60 developed leaf spot lesions. These included 17 of the 20 Gramineae tested, including corn (Lin et al. 2011). Exserohilum rostratum has been recovered from lesions on rice (Cardona and González 2007; Mahmad Toher et al. 2015), and it also causes leaf spot on bottle gourd [Lagenaria siceraria (Molina) Standl.] leaves (Choudhary et al. 2018) and pineapple (Ananas comosus (L.) Merr.] leaves (Luo et al. 2011). In July 2009 , atypical symptoms of a leaf spot disease from which E. rostratum was cultured were observed on mature pineapple leaves in Chengmai County in China; approximately $15 \%$ of plants propagated from suckers became symptomatic after 150 to $300 \mathrm{~d}$, eventually causing a $3 \%$ to $10 \%$ yield loss (Luo et al. 2011). Exserohilum rostratum has been implicated as causing root rot of lettuce (Lactuca sativa L.) (Alamri et al. 2019). Further, it is frequently mentioned as a pathogen in humans, as exemplified by Alajmi et al. (2019).

Based on results of greenhouse studies, a mixture of Drechslera gigantea (Heald \& F.A. Wolf) S. Ito, Exserohilum longirostratum (Subram.) Sivan, and E. rostratum has been recommended as a biocontrol for $S$. halepense and six other weed species (Chandramohan and Charudattan 2001). The tests included inoculation of seedlings of six sorghum and six corn varieties as well as other garden and crop species that were all either resistant or immune. No follow-up reports on in-field applications were found.

Once again, the use of DNA sequence information, in this case from nine different regions, has led to significant reevaluation of Exserohilum spp. Most notably, E. rostratum was revealed as conspecific with other previously described Exserohilum species such as Exserohilum antillanum R.F. Castañeda, Guarro \& Cano, Exserohilum gedarefense (El Shafie) Alcorn, Exserohilum leptochloae Y. Nisik. \& C. Miyake, Exserohilum longirostratum (Subram.) Sivan., Exserohilum macginnisii A.A. Padhye \& Ajello, and Exserohilum prolatum K.J. Leonard \& Suggs. Isolates from sorghum still fell into seven different species, most commonly Exserohilum turcicum (Pass.) Leonard \& Sugg. (Hernández-Restrepo et al. 2018).

Exserohilum turcicum is most widely known as the cause of northern corn leaf blight in corn (Chiang et al. 1989b). It is one of the most common and economically significant fungal leaf diseases of corn in the north-central United States and Ontario, Canada (Jindal et al. 2019; Weems and Bradley 2017), and this destructive pathogen can reduce the grain yield of corn by more than 90\% (Pant et al. 2000). Other studies have shown mixed results as far as host specificity of isolates. Reports describing recovery from S. halepense include Chiang et al. (1989b), who found that $S$. halepense seedlings are susceptible to isolates recovered from Sorghum spp. (Sudan grass [Sorghum bicolor (L.) Moench ssp. drummondi (Nees ex Steud.) de Wet \& Harlan], S. halepense, and broomcorn [Sorghum vulgare Pers. var. technicum (Koern.) Jáv.]); S. halepense has been identified as an overwintering host (Levy 1984). It can also provide a suitable medium in culture for crosses involving the teleomorph (Setosphaeria turcica) (Moghaddam and Pataky 1994). Sorghum host differentials have been identified in India that show varying responses across locations, indicating that multiple pathotypes are present (Mathur et al. 2011). However, lack of cross infection between corn and $S$. halepense isolates has also been reported (Abadi et al. 1996). In one study, an E. turcicum originally isolated from $S$. halepense in Italy was inoculated to 40 varieties of cultivated sorghum, 25 hybrids of corn, and 5 varieties of durum wheat, bread wheat, oat (Avena sativa L.), barley and rice. Overall, only 15 varieties of cultivated sorghum showed a mild level of infection (Del Serrone and Fornasari 1995). In a similar study, a North Carolina isolate of E. turcicum that had been isolated from S. halepense caused moderate to severe damage to sorghum and corn (Chiang et al. 1989c). So, S. halepense may well act as a significant reservoir for E. turcicum.

\section{Claviceps Africana}

Sorghum ergot, caused by Claviceps africana Frederickson, Mantle \& De Milliano, is a disease that replaces the seed on panicles of infected florets with sphacelia/sclerotia (Odvody et al. 2002). In India, losses of $10 \%$ to $80 \%$ have been reported in hybrid seed production fields, and ergot epiphytotics in Zimbabwe result in regular annual losses of $12 \%$ to $25 \%$ and occasionally in total losses (Bandyopadhyay et al. 1998). Although now global in nature, sorghum ergot was not known to be in the Western Hemisphere before 1995. After being reported in Mexico (Velasquez-Valle et al. 1998), it was later seen in Texas in the lower Rio Grande valley, where it was found in both sorghum fields and adjacent stands of S. halepense (Isakeit et al. 2007). Because of the mild climate in the Rio Grande region, conidia can be produced year-round, providing a continual source of inoculum. Consequently, $S$. halepense has been suggested as a likely source of recurring disease (Odvody and Isaskeit 1997; Prom et al. 2005), allowing annual spread throughout U.S. sorghum production regions as the growing season advances northward.

\section{Sporisorium cruentum}

In a greenhouse study, teliospores of Sphacelotheca holci Jack. [= Sphaceloiheca cruenta (Kühn.) Potter] (synonym to Sporisorium cruentum (Kühn) K. Vánky), that causes loose kernel smut in sorghum, infected $S$. halepense systemically after inoculation of cut stems (Massion and Lindow 1986). S. cruentum has been suggested as a biological control for S. halepense (Millhollon 2000), but isolates from $S$. halepense also cause loose kernel smut in sorghum as reported by Dean (1966). Recently, a sample from S. halepense was shown to readily infect sorghum cultivar 'BTx643' plants (Prom et al. 2017a), making any use to control $S$. halepense a potential problem for nearby sorghum. In Ethiopia, the incidence of covered kernel smut is estimated to be around 50\% (Azanaw et al. 2020; Mengistu 1982).

\section{Colletotrichum sublineola}

Before 1992 (and sometimes since) the species name graminicola was used to identify pathogens in the genus Colletotrichum that cause anthracnose on corn, sorghum, and other gramineae crops, 
with some isolates being identified as having restricted host specificity. However, based on differences between perfect stages (Glomerella) (Vaillancourt and Hanau 1992) and ITS sequencing (Sherriff et al. 1995), Colletotrichum sublineola Henn. ex Sacc. \& Trotter 1913 (or sublineolum) is now used for isolates that infect sorghum. Sorghum halepense isolates of C. sublineola, have been shown to infect sorghum cultivars (Xavier et al. 2018). Conversely, under ideal conditions in a greenhouse, only inoculation at late growth stages of $S$. halepense led to infection by C. sublineola isolates originating from grain sorghum (Ahn et al. 2020). In 1989, it was reported that $C$. graminicola extracted from $S$. halepense caused moderate to severe leaf damage on corn and sorghum; even oats and barley were slightly affected by this isolate (Chiang et al. 1989c). However, this was before the separation of the species names graminicola and sublineola in 1992, so the identity of the Colletotrichum isolate used in the study is not clear, nor is it known whether other species also can reproduce on S. halepense. In sorghum, losses caused by the panicle phase of anthracnose in terms of grain yield are generally $2 \%$ to $15 \%$ but may be up to $30 \%$ to $50 \%$ (Frederiksen and Odvody 2000), so S. halepense and possible other alternate hosts do pose a potential threat for sorghum production.

Gloeocercospora sorghi

Gloeocercospora sorghi Bain \& Edgerton causes zonate leaf spot on sorghum and has been recovered from $S$. halepense showing the same symptoms (Chiang et al. 1989a). Inoculation with an isolate of G. sorghi from S. halepense caused damage to corn and sorghum; mycelial growth and sclerotia appeared on incubated leaves of Sorghum spp. but not other species, which indicates that G. sorghi was compatible only with Sorghum spp. (Chiang et al. 1989c). Although the distinctive pattern of infection of sorghum leaves show it is a very common disease, it seems not to cause sufficient levels of yield loss to stimulate further research. Gloeocercospora sorghi has been tested as bioherbicide for S. halepense (Mitchell et al. 2003), but the paper also pointed out it was highly virulent in other sorghums.

\section{Ramulispora sorghicola}

Oval leaf spot caused by Ramulispora sorghicola E. Harris was observed on sorghum and S. halepense near Beeville, TX, during August 2002 (Odvody et al. 2006). The observation that rows of sorghum nearest to $S$. halepense displayed the same symptoms and that conidial cultures were found to reproduce the disease on both hosts implies that $S$. halepense was serving as a spreader. In winter months, oval leaf spot was mostly found on S. halepense, further strengthening the idea that $S$. halepense was the primary source. Because resistant sorghum cultivars are available, $R$. sorghicola has not led to significant sorghum yield losses (Odvody et al. 2006).

\section{Basidiomycota}

A few fungal pathogens of $S$. halepense are categorized in phylum basidiomycota.

\section{Rhizoctonia solani}

Rhizoctonia solani Kühn [teleomorph Thanatephorus cucumeris (A.B. Frank) Donk.], an undefined binucleate Rhizoctonia, and Rhizoctonia zeae Voorhees (teleomorph Waitea circinata Warcup \& Talbot AG Z) were isolated from S. halepense growing in Turkey (Demirci and Eken 1999; Demirci et al. 2002). Rhizoctonia solani is a soilborne plant pathogen with considerable diversity in cultural morphology, host range, and aggressiveness
(Ajayi-Oyetunde and Bradley 2018). Heterokaryon compatibility subdivides the species into 14 anastomosis groups that may differ in host range, several of which (AG-1A AG1B, AG4, and AG-5) have been isolated from corn ( $\mathrm{Li}$ et al. 1998) and, except for AG-1B, from sorghum (Gao 1987). AG-1 isolates are also pathogens of soybean, and soybean isolates have been shown to infect $S$. halepense (Black et al. 1996). The R. solani that causes severe seedling damping-off up to $80 \%$ to $100 \%$ and final yield loss of up to $30 \%$ of oilseed rape (Brassica napus L.) worldwide belongs to AG21 (Kataria and Verma 1992; Khangura et al. 1999; Sturrock et al. 2015; Tahvonen et al. 1984).

While $R$. zeae derives its name from a corn disease described in 1934 (Voorhees 1934), it has also been reported to infect turfgrass in Florida, Ohio, and Ontario (Elliott 1999; Hsiang and Masilamany 2007) and rice (Sifat and Monjil 2017). More research is required to determine whether $S$. halepense serves as a source of Rhizoctonia diseases of crop species and, if so, which of the anastomosis groups are involved.

\section{Sporisorium reilianum}

Sporisorium reilianum (J.G. Kühn) Langdon \& Full. (formerly Sphacelothca reiliana), the cause of head smut in sorghum and corn, may represent an exception where $S$. halepense is not a host. Yield losses attributed to $S$. reilianum are estimated to be as high as $80 \%$ in corn (Frederiksen 1977; Jin et al. 2000; Yu et al. 2014). Attempts to create infections using sporidia from cultures derived from teliospores collected from infected sorghum did not produce infection from spray, needle, or root-dip inoculation on any of several S. halepense cultivars tested (personal observations).

\section{Bacterial Diseases of Sorghum halepense}

More than 2,000 bacterial species have been reported as pathogens to more than 2,500 species of various plant hosts (Frederiksen and Odvody 2000). Among them, relatively few bacterial pathogens are known to be harbored in $S$. halepense.

\section{Clavibacter michiganensis}

Clavibacter michiganensis subsp. nebraskensis (Cmn), causal agent of Goss's wilt of corn, sugarcane, and sorghum, can also infect $S$. halepense, which confirms that $S$. halepense may serve as alternate host (Ikley et al. 2015). In this case, plants were inoculated with a sample originally from corn. Bacteria from resulting lesions were isolated and verified via Agdia $^{\circ}$ immunostrips specific for $\mathrm{Cmn}$, and Koch's postulates were fulfilled by showing pathogenicity on corn. Disease incidence in affected cornfields ranged from $20 \%$ to $60 \%$, and significant yield loss was reported (Ruhl et al. 2009). Spread from S. halepense to corn or other crops could severely reduce yield.

\section{Pseudomonas syringae}

Pseudomonas syringae Van Hall was recovered from a lesion on a $S$. halepense leaf that caused circular to ellipsoidal, tan-orange-red to blackish-purple spots (Mikulas and Sule 1979). Bacterial leaf spot has not been reported to be of widespread occurrence in sorghum, so control measures are not likely to be warranted (Frederiksen and Odvody 2000).

\section{Rickettsia-like Bacteria}

Rickettsia-like bacteria (RLB) were consistently observed in $\mathrm{KOH}$ extracts of $S$. halepense stems collected in peach [Prunus persica 
(L.) Batsch] orchards with Phony disease. Although the RLB from $S$. halepense could not be cultured, it was antigenically similar to the RLB from infected peach trees, and its high incidence in orchards with Phony disease suggested a potential causal association through transmission via leafhoppers (Weaver et al. 1980).

\section{Xanthomonas vasicola}

Xanthomonas vasicola pv. Vasculorum causes bacterial leaf streak in corn, and in a recent study, it was revealed that $S$. halepense is an alternative host of X. vasicola (Hartman 2018). That study also showed that cultivars of grain sorghum, oats, and rice also developed symptoms when inoculated with bacterial cultures grown from a corn isolate. The same bacterium is known to cause gummy disease of sugarcane (Hartman 2018). The impact of bacterial leaf streak on yield is not yet known, but it is not considered a major disease on crops (Byamukama et al. 2020).

\section{Xylella fastidiosa}

Xylella fastidiosa, a common bacterial pathogen that causes Pierce's disease in grapes (Vitis aestivalis Michx.), was found in S. halepense in 1959 (Turner and Pollard 1959). More recently, inoculation of weed species with sharpshooter insects [Homalodisca vitripennis (Germar), formerly known as $H$. coagulate (Say); Xyphon fulgidum (Nottingham); and Graphocephala atropunctata (Signoret)] previously fed on infected grapes for $4 \mathrm{~d}$ found that 14 of 62 inoculated $S$. halepense plants maintained detectable levels of the pathogen, with systemic spread in two of the plants (Wistrom and Purcell 2005). However, an assay made the following year showed that many other weeds in almond [Prunus dulcis (Mill.) D.A. Webb] orchards in the same region also harbored $X$. fastidiosa, and in that survey, no positive tests were found on S. halepense (Shapland et al. 2006).

The cost of Pierce's disease in California is approximately $\$ 104.4$ million $\mathrm{yr}^{-1}$ (Tumber et al. 2014), so weed as well as insect control measures are warranted.

\section{Viral Diseases of Sorghum halepense}

A 1965 report of a virus found on S. halepense in California assumed it came from nearby sugarcane, and although it had some serologic cross reactions, it was found to be indistinguishable from maize mosaic virus (MMV) and in fact was not infectious to sugarcane (Shephard 1965).

\section{Sorghum halepense Mosaic Virus}

Johnsongrass mosaic virus (JGMV), now recognized as a member of a family of potyviruses, infects corn, sorghum, and S. halepense but not wheat or oat (Stewart et al. 2017). The JGMV complete RNA genome sequence in GenBank is 9,779-bases long. While antibody-based tests can differentiate JGMV, SCMV (sugarcane), MDMV (maize dwarf), and SrMV (sorghum) as being antigenically distinct (McKern et al. 1990), comparisons of the polyprotein or coat protein amino acid sequences show significant similarity to one another and also to Pennisetum mosaic virus (Laidlaw et al. 2004). JGMV does not show high similarity to MMV, which is larger, at 12,133 nucleotides. Recently, JGMV has been implicated as the sole (Stewart et al. 2017) or as a participating (Redinbaugh and Stewart 2018) virus component in a disease called maize lethal necrosis, a serious emerging disease on corn in East Africa.

\section{Maize Dwarf Mosaic Virus and Maize Chlorotic Dwarf Virus}

Two major U.S. corn viruses, MDMV and MCDV, can also be isolated from $S$. halepense. A virus disease problem emerged in southern Ohio and surrounding regions in the 1960s (Stewart et al. 2014). MDMV caused up to $70 \%$ loss in corn yield globally since the 1960s (Kannan et al. 2018). Similarly, MCDV is known to cause significant height (34\% average) and yield reductions $(72 \%$ average) (Louie et al. 1990). Spread of MDMV from introduced virus-infected $S$. halepense to adjacent susceptible corn in experimental plots was evaluated during 1979 and 1980 (Knoke et al. 1983). Field experiments were conducted to evaluate the hypothesis that $S$. halepense control in corn causes increased MDMV and MCDV disease severity because of increased movement of insect vectors from dying $S$. halepense to the corn crop (Eberwine and Hagood 1995). In a follow-up study that took advantage of newer technology, reverse transcriptase sequencing reads made from RNA extracts of $S$. halepense and corn in the same region of southern Ohio, MDMV, MCDV, SCMV, SrMV, and MCMV sequences were found in both hosts, but JGMV was not detected (Stewart et al. 2014). MDMV was also detected on S. halepense in Oklahoma (Wijayasekara and Ali 2017). In earlier studies, the leafhopper vector was allowed to acquire MCDV from corn or $S$. halepense source plants positioned in the center of corn plots. Results showed that spread from $S$. halepense was lower than if the insects fed on infected corn (Rodriguez et al. 1993).

\section{Sugarcane Mosaic Virus}

Sugarcane mosaic virus (SCMV), a causal agent of mosaic and dwarf mosaic on corn, sugarcane, and sorghum, was prevalent on S. halepense in marginal areas of cornfields (Mohammadi et al. 2006). SCMV, which is considered as one of the top 10 most economically damaging plant viruses, reduces sorghum and sugarcane yields around $10 \%$ to $35 \%$ and corn yield around $20 \%$ to 50\% (Braidwood et al. 2019; Rybicki 2015; Viswanathan and Balamuralikrishnan 2005; Zhu et al. 2014), so removing S. halepense around fields is warranted.

\section{Oomycete Diseases of Sorghum halepense}

\section{Peronoscleospora sorghi}

Sorghum downy mildew, incited by Peronoscleospora sorghi (Weston and Uppal) C.G. Shaw, has been known for almost 50 yr to be pathogenic to S. halepense (Amador et al. 1974). In 2000 , it was observed on corn, sorghum, and S. halepense in Uganda (Bigirwa et al. 2000). In that report, cross inoculation was demonstrated for spores taken from each host, but the symptoms were least on corn. However, within the southern epidemic zone in Nigeria, Zimbabwe, Zambia, Mozambique, and Rwanda, yield loss of corn was estimated to be $11.7 \%$; individual fields had up to $95 \%$ incidence of systemically infected plants (Bock et al. 1998). Pathotypes of $P$. sorghi have been defined based on differences in host differentials in sorghum, but no similar tests have been reported for $S$. halepense.

\section{Current Mainstream Technologies for Studying Diseases in Sorghum halepense}

Sorghum halepense has been both a known and suspected reservoir of pathogens that have potential to cause diseases in other crops. Understanding of diseases of $S$. halepense that can potentially 


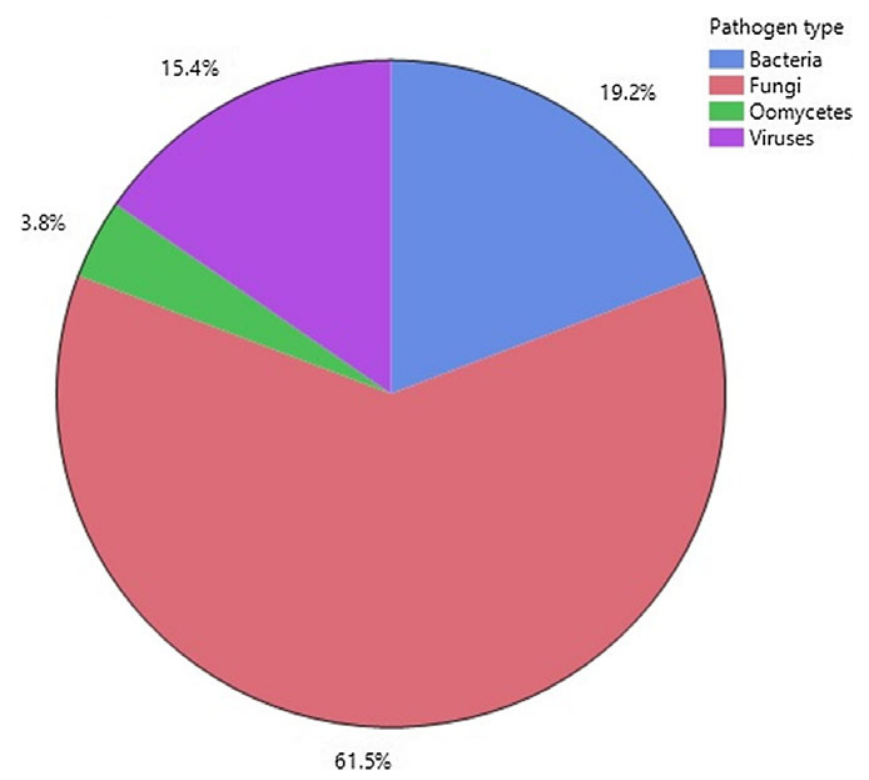

Figure 1. A pie chart that summarizes the proportions of the four categories of pathogens found in Sorghum halepense. Percentages displayed are rounded to the nearest tenth of a percent, and therefore do not total $100 \%$.

cross-infect agronomically important crops can provide valuable information for crop protection against the pathogens. Among four types of pathogens, fungal pathogens for other host plants were most frequently detected in S. halepense (Figure 1). As would be predicted based on their close phylogenetic relationship based on DNA sequencing, sorghum pathogens were more frequently found in S. halepense compared with pathogens of other crops. However, many of those same pathogens have also been found on other weeds, and only a few studies have been made since the advent of DNA-based sequence information, which can be used to more accurately define species or strains showing host specificity. Likewise, essentially no studies have investigated the infection process or reproductive cycle of pathogens of $S$. halepense. As a consequence, for most pathogens, the role of $S$. halepense as a reservoir remains to be investigated. Recent studies of based on real-time qRT-PCR analysis using primers designed for sorghum genes found upregulated defense-related genes in $S$. halepense when inoculated with C. sublineola (Ahn et al. 2018). Although never directly applied to $S$. halepense, recent technologies such as genome-wide association studies (GWAS) and RNA sequencing (RNA-seq) are expected to be applied in $S$. halepense to study diseases of $S$. halepense and their responses to various pathogens.

\section{Potential for Using Diseases of Sorghum halepense for Its Biological Control}

As indicated earlier, several pathogens such as S. cruentum, G. sorghi, and a mix of three fungal pathogens (D. gigantea, E. longirostratum, and E. rostratum) have been studied or even recommended as biocontrol agents (Chandramohan and Charudattan 2001; Millhollon 2000; Mitchell et al. 2003). In some cases, the pathogens have later been found to cause disease in at least some cultivars of sorghum or, as in the case of G. sorghi, S. halepense was found to regrow after initial damage, a likely result from sprouting of rhizomes. Sorghum halepense rhizomes are known to allow pathogens such as MDMV to overwinter (Williams et al. 1966). Also, sorghum and $S$. halepense seedlings may contain high levels of dhurrin, a cyanogenic glucoside that may contribute to juvenile resistance to pathogens and insects (Ahn et al. 2020). Consequently, use of plant pathogens for inoculation at multiple stages of plant growth may be required for confirmation. For example, when 21 and $26 \mathrm{~S}$. halepense cultivars grown in a greenhouse were inoculated at the 8-leaf stage with C. sublineola isolates FSP35 and FSP53, respectively, which are highly virulent on sorghum, no lesion with acervuli formation was found (Ahn et al. 2018, 2020). However, when the same 21 S. halepense cultivars were inoculated post-heading with FSP35, high numbers of sporulating lesions were present (Ahn et al. 2020). The appearance of symptoms does not guarantee pathogen reproduction has occurred and thus cannot be taken as proof of transmission in either direction, because avirulent strains of a pathogen, or even non-pathogens, may induce defense reactions that have visible symptoms, even though the pathogen does not produce infective propagules.

\section{Potential for Leveraging Sorghum halepense Disease-Resistant Genes for Crop Trait Development}

Based on real-time qRT-PCR analysis using primers designed for sorghum genes, $S$. halepense has been shown to upregulate defenserelated genes, including chalcone synthase 8 , thaumatin-like protein, and flavonoid-3'-hydroxylase, when inoculated with C. sublineola (Ahn et al. 2018; Ahn et al. 2019b). Bermudagrass southern mosaic virus (BgSMV), a nonpathogenic virus to $S$. halepense, triggered genes related to plant defense responses, including nonexpressor of pathogenesis related genes 1 (NPR1), peroxiredoxin, and S-adenosyl methionine synthase (SAM), to higher levels than in S. halepense plants inoculated with MDMV (Mostafavi et al. 2019). In sorghum, nonpathogenic fungi have been known to activate defense-related genes of sorghum with distinctive patterns that are comparable to patterns caused by pathogenic fungi (Lo et al. 1999). Xavier et al. (2018) reported that C. sublineola isolates collected from $S$. halepense are phylogenetically distinctive from the isolates collected from sorghum. Therefore, distinct patterns of defense-related gene expression are expected when sorghums are inoculated with C. sublineola isolates collected from $S$. halepense.

Sorghum halepense may provide a source of genes for resistance to pathogens. As a tetraploid that evolved from hybridization between S. bicolor and Sorghum propinquum (Kunth) Hitchc. around 96 million years ago (Paterson et al. 2020), S. halepense is expected to have duplicates of many genes, including resistance $\mathrm{R}$ genes that trigger response to effectors from a potential pathogen. Not only are there more R genes present, but it is likely that a change in an $\mathrm{R}$ gene in one genome would not lead to loss of response to a specific elicitor because of the orthologous gene in the other genome. While mapping of $\mathrm{R}$ genes has not been carried out in S. halepense, progress is being made in sorghum, in which DNA-based tags for R genes and defense response genes are being identified. In sorghum, GWAS have been used to identify defenserelated single-nucleotide polymorphisms (SNPs) to pathogens such as C. sublineola (Ahn et al. 2019a; Cuevas et al. 2018; Prom et al. 2019) and E. turcicum (Ding et al. 2015; Zhang et al. 2020). As more of these genes become identified, it will be interesting to compare both gene sequences and levels of expression following inoculation with a pathogen. It will also be interesting to identify putative $\mathrm{R}$ genes in $S$. halepense that differ from those in sorghum, as they could provide a source of ready-made 
resistance suitable for transfer to other crops, especially if the gene product can be shown to interact with a specific elicitor.

\section{Future Research Directions}

Diseases of $S$. halepense have not been extensively explored, and there are unknown pathogens of $S$. halepense as well (personal observations). Future research should take advantage of DNA sequence information for identification of species, and even pathotypes, when testing cross infection of potential pathogens that may transfer between major crops and $S$. halepense.

In summary, while $S$. halepense shares many pathogens with important crops, proof of a role in crop disease in many cases remains elusive. Factors that must be considered include:

1. Verification of the species causing disease in both hosts by successful cross inoculation and recovery, as backed up by DNA sequence information. This would also eliminate nearly identical pathogens that have developed host specificity through coevolution with the different hosts.

2. Because environmental conditions, including plant developmental stage, are critical for successful pathogen reproduction, tests must be made in conducive environments and at multiple stages of plant growth. In the meantime, eliminating S. halepense, especially stands growing near sorghum, is important.

\section{Overall Lessons}

Sorghum halepense is one of the most problematic weeds in the world due to rapid growth and wide dispersal of seeds and rhizomes. In addition, it is clear that $S$. halepense carries fungal, bacterial, viral, and oomycete pathogens that may infect other crops. However, in many studies, rigorous proof that it is the same pathogen is lacking, a problem that can now be addressed using DNA sequence information.

As for future research directions, possible suggestions include studies to identify possible genes for resistance, either broadscale or to specific races of fungal pathogens, which are areas that have not been explored because $S$. halepense is a weed. Despite the fact that diseases of $S$. halepense are not well studied, it is essential to understand that $S$. halepense could spread known and possible unknown diseases to other crops. Also, if it is possible to find strains of pathogens that heavily damage $S$. halepense but cause no/mild symptom(s) in other plants, it may be possible to use these pathogens as biocontrol agents. Further, genes from S. halepense that trigger hypersensitive responses to various pathogens may be useful in creating improved pathogen resistance in crops such as sorghum by interspecific crosses or gene transfer and editing technologies.

Acknowledgments. Support provided from AFRI, NIFA, USDA award no. 20156800423492. No conflicts of interest have been declared.

\section{References}

Abadi R, Perl-Treves R, Levy Y (1996) Molecular variability among Exserohilum turcicum isolates using RAPD (random amplified polymorphic DNA). Can J Plant Pathol 18:29-34

Acciaresi H, Mónaco C (1999) First report of Bipolaris sorghicola on Johnsongrass in Argentina. Plant Dis 83:965

Ahn E, Hu Z, Perumal R, Prom LK, Odvody G, Upadhyaya HD, Magill C (2019a) Genome wide association analysis of sorghum mini core lines regarding anthracnose, downy mildew, and head smut. PLoS ONE 14: e0216671

Ahn E, Odvody G, Prom LK, Magill C (2020) Late growth stages of Johnsongrass can act as an alternate host of Colletotrichum sublineola. Plant Health Prog 21:60-62

Ahn E, Prom LK, Odvody G, Magill C (2018) Responses of Johnsongrass against sorghum anthracnose isolates. J Plant Pathol Microbiol 9:7

Ahn E, Prom LK, Odvody G, Magill C (2019b) Defense responses against the sorghum anthracnose pathogen in leaf blade and midrib tissue of Johnsongrass and sorghum. Physiol Mol Plant Pathol 106:81-86

Ajayi-Oyetunde OO, Bradley CA (2018) Rhizoctonia solani: taxonomy, population biology and management of rhizoctonia seedling disease of soybean. Plant Pathol 67:3-17

Akram W, Anjum T, Ahmad A, Moeen R (2014) First report of Curvularia lunata causing leaf spots on Sorghum bicolor from Pakistan. Plant Dis 98:1007

Alajmi S, Koratum RM, Khan Z, Ahmad S, Jeragh A, Ibrahim H, Joseph L, Varghese $S$ (2019) Allergic fungal sinusitis caused by Exserohilum rostratum and literature review. Mycopathologia 184:89-96

Alamri SAM, Hashem M, Mostafa YS, Nafady NA, Abo-Elyousr KAM (2019) Biological control of root rot in lettuce caused by Exserohilum rostratum and Fusarium oxysporum via induction of the defense mechanism. Biol Control 128:76-84

Amador J, Berry RW, Frederiksen RA, Horne CW, Thames WH, Toler RW (1974) Sorghum Diseases. College Station, TX: Texas Agriculture Extension. Texas A \& M University Bull. No. 1085. 4 p

Arora M, Dhurwe U (2014) Grain yield losses due to charcoal rot of sorghum infected by Macrophomina phaseolina. Global J Biol Agric Health Sci 3: 267-269

Ávila MR, Dall'Agnol M, Martinelli JA, Silva GBPD, Bremm C, Nunes T (2017) Selection of alfalfa genotypes for resistance to the foliar pathogen Curvularia geniculata. An Acad Bras Cienc 89:1801-1813

Azanaw A, Gelaye M, Kefale Y (2020) On farm training and demonstration of covered Smut (Sphacelotheca sorghi Clint) management technologies on sorghum. Asian Business Consortium 10:7-12

Bandyopadhyay R, Frederickson DE, McLaren NW, Odvody GN, Ryley MJ (1998) Ergot: a new disease threat to sorghum in the Americas and Australias. Plant Dis 82:356-367

Bandyopadhyay R, Mughogho LK, Satyanarayana MV, Kalisz ME (1991) Occurrence of airborne spores of fungi causing grain mould over a sorghum crop. Mycol Res 95:1315-1320

Berbee ML, Pirseyedi M, Hubbard S (1999) Cochliobolus phylogenetics and the origin of known, highly virulent pathogens, inferred from ITS and glyceraldehyde-3-phosphate dehydrogenase gene sequences. Mycologia 91:964-977

Bigirwa G, Adipala E, Esele JP, Cardwell KF (2000) Reaction of maize, sorghum and Johnson grass to Peronosclerospora sorghi. Int J Pest Manag 46:1-6

Bisht S, Balodi R, Ghatak A, Kumar P (2018) Determination of susceptible growth stage and efficacy of fungicidal management of Curvularia leaf spot of maize caused by Curvularia lunata (Wakker) Boedijn. Maydica 61:5

Black BD, Griffin JL, Russin JS, Snow JP (1996) Weed hosts for Rhizoctonia solani, causal agent for Rhizoctonia foliar blight of soybean (Glycine max). Weed Technol 10:865-869

Bock CH, Jeger MJ, Mughoho LK, Cardwell KF, Adenle V, Mtisi E, Akpa AD, Kaula G, Mukasambina D, Blair-Myers C (1998) Occurrence and distribution of Peronosclerospora sorghi [Weston and Uppal (Shaw)] in selected countries of West and Southern Africa. Crop Prot 17:427-439

Braidwood L, Müller SY, Baulcombe D (2019) Extensive recombination challenges the utility of sugarcane mosaic virus phylogeny and strain typing. Sci Rep 9:20067

Brecht MO, Stiles CM, Datnoff LE (2007) Evaluation of pathogenicity of Bipolaris and Curvularia spp. on dwarf and ultradwarf bermudagrasses in Florida. Plant Health Prog 8:30

Burke IC, Wilcut J, Cranmer J (2006) Cross-resistance of a Johnsongrass (Sorghum halepense) biotype to aryloxyphenoxypropionate and cyclohexanedione herbicides. Weed Technol 20:571-575

Byamukama E, Tande C, Nampijja M, Mathew F, Bleakley B (2020) First report of Xanthomonas vasicola pv. vasculorum, the causal agent of bacterial leaf streak of corn, in South Dakota. Plant Dis 104:1851 
Cardona R, González MS (2007) First report of Exserohilum rostratum associated with rice seed in Venezuela. Plant Dis 91:226-226

Chandramohan S, Charudattan R (2001) Control of seven grasses with a mixture of three fungal pathogens with restricted host ranges. Biol Control 22:246-255

Chiang M-Y, Leonard KJ, Van Dyke CG (1989a) Bipolaris halepense: a new species from Sorghum halepense (Johnsongrass). Mycologia 81:532-538

Chiang M-Y, Van Dyke CG, Chilton WS (1989b) Four foliar pathogenic fungi for controlling seedling Johnsongrass (Sorghum halepense). Weed Sci 37:802-809

Chiang M-Y, Van Dyke CG, Leonard KJ (1989c) Evaluation of endemic foliar fungi for potential biological control of johnsongrass (Sorghum halepense): screening and host range tests. Plant Dis 73:459-464

Choudhary M, Sardana HR, Bhat MN, Gurjar MS (2018) First report of leaf spot disease caused by Exserohilum rostratum on bottle gourd in India. Plant Dis 102:2042

Cuevas HE, Prom LK, Cooper EA, Knoll JE, Ni X (2018) Genome-wide association mapping of anthracnose (Colletotrichum sublineolum) resistance in the U.S. sorghum association panel. Plant Genome 11, 10.3835/ plantgenome2017.11.0099.

Dean JL (1966) Local infection of sorghum by the Johnson grass loose kernel smut fungus. Phytopathology 56:1342-1344

Del Serrone P, Fornasari L (1995) Host range and evaluation of an isolate of Exserohulum turcicum on some populations of Johnsongrass (Sorghum halepense). Pages 487-492 in Delfosse ES, Scott RR, eds. Proceedings of the Eighth International Symposium on Biological Control of Weeds (1992). Lincoln Universtiy, Canterbury, NZ: DSIR/CSIRO

Demirci E, Eken C (1999) First report of Rhizoctonia zeae in Turkey. Plant Dis 83:200

Demirci E, Eken C, Zengin H (2002) First report of Rhizoctonia solani and binucleate Rhizoctonia from Johnsongrass in Turkey. Plant Pathol 51:391

Ding J, Ali F, Chen G, Li H, Mahuku G, Yang N, Narro L, Magorokosho C, Makumbi D, Yan J (2015) Genome-wide association mapping reveals novel sources of resistance to northern corn leaf blight in maize. BMC Plant Biol 15:206

Ding Fa Z, PeiXin H, XiuYing W, TingJun M, Zhang DF, He PX, Wei XY, Ming TJ (1999) Damage and control index of maize leaf spot Curvularia lunata. Plant Prot 25:12-15

Eberwine JW, Hagood ES (1995) Effect of Johnsongrass (Sorghum halepense) control on the severity of virus diseases of corn (Zea mays). Weed Technol 9:73-79

Elliott ML (1999) Comparison of Rhizoctonia zeae isolates from Florida and Ohio turfgrasses. HortScience 34:298-300

Frederiksen R, Odvody G (2000) Compendium of Sorghum Diseases. St Paul, MN: American Phytopathological Society. 78 p

Frederiksen RA (1977) Head smuts of corn and sorghum. Pages 89-104 in Proceedings of the 32nd Corn and Sorghum Research Conference. Chicago

Fuhlbohm MJ, Ryley MJ, Aitken EAB (2012) New weed hosts of Macrophomina phaseolina in Australia. Australas Plant Dis Notes 7:193-195

Gao W (1987) Preliminary studies on etiology of sheath blight of maize, sorghum and millet in North China. Chin J Plant Ecol 4:247-251

Hartman T (2018) Investigation of Alternative Hosts and Agronomic Factors Affecting Xanthomonas vasicola pv. vasculorum, Causal Agent of Bacterial Leaf Streak of Corn. MS thesis. Lincoln: University of NebraskaLincoln. 101 p. http://digitalcommons.unl.edu/agronhortdiss/152. Accessed: Auguest 1, 2020

Hernández-Restrepo M, Madrid H, Tan YP, da Cunha KC, Gené J, Guarro J, Crous PW (2018) Multi-locus phylogeny and taxonomy of Exserohilum. Persoonia 41:71-108

Hodges CF, Madsen JP (1979) Leaf senescence as a factor in the competitive and synergistic interactions of Drechslera sorokiniana and Curvularia geniculata on Poa pratensis. Can J Bot 57:1706-1711

Hsiang T, Masilamany P (2007) First report of Rhizoctonia zeae on turfgrass in Ontario. Plant Pathol 56:350

Ikley JT, Wise KA, Johnson WG (2015) Annual ryegrass (Lolium multiflorum), Johnsongrass (Sorghum halepense), and large crabgrass (Digitaria sanguinalis) are alternative hosts for Clavibacter michiganensis subsp. nebraskensis, causal agent of Goss's wilt of corn. Weed Sci 63:901-909
Isakeit T, Odvody GN, Shelby RA (2007) First report of sorghum ergot caused by Claviceps africana in the United States. Plant Dis 82:592

Jin QM, Li JP, Zhang XW (2000) Establishment IPM of system of corn diseases and pest insects in the spring corn belt. J Maize Sci 8:84-88

Jindal KK, Tenuta AU, Woldemariam T, Zhu X, Hooker DC, Reid LM (2019) Occurrence and distribution of physiological races of Exserohilum turcicum in Ontario, Canada. Plant Dis 103:1450-1457

Kannan M, Ismail I, Bunawan H (2018) Maize dwarf mosaic virus: from genome to disease management. Viruses 10:492

Kataria H, Verma P (1992) Rhizoctonia solani damping-off and root rot in oilseed rape and canola. Crop Prot 11:8-13

Katewa R, Mathur K, Bunker RN (2006) Assessment of losses in sorghum due to target leaf spot (Bipolaris sorghicola) at varying disease severity levels. Indian Phytopathol 59:237-239

Khan S. N. (2007). Macrophomina phaseolina as causal agent for charcoal rot of sunflower. Mycopathology 5:111-118

Khangura RK, Barbetti MJ, Sweetingham MW (1999) Characterization and pathogenicity of Rhizoctonia species on canola. Plant Dis 83:714-721

King S, Hagood ES Jr (2003) The effect of Johnsongrass (Sorghum halepense) control method on the incidence and severity of virus diseases in glyphosate-tolerant corn (Zea mays). Weed Technol 17:503-508

Knoke JK, Louie R, Madden LV, Gordon DT (1983) Spread of maize dwarf mosaic virus from Johnsongrass to corn. Plant Dis 67:367-370

Laidlaw HK, Persley DM, Pallaghy CK, Godwin ID (2004) Sequence diversity in the coat protein coding region of the genome RNA of Johnsongrass mosaic virus in Australia. Arch Virol 149:1633-1641

Lal M, Kumar S, Ali M, Khan A, Singh V, Murti S (2013) Host range, susceptibility period of Curvularia lunata causing leaf spot of black gram and germplasm screening. Agriways 1:142-146

Levy Y (1984) The overwintering of Exserohilum turcicum in Israel. Phytoparasitica 12:177-182

Li HR, Wu BC, Yan SQ (1998) Aetiology of rhizoctonia in sheath blight of maize in Sichuan. Plant Pathol 47:16-21

Lin SH, Huang SL, Li QQ, Hu CJ, Fu G, Qin LP, Ma YF, Xie L, Cen ZL, Yan WH (2011) Characterization of Exserohilum rostratum, a new causal agent of banana leaf spot disease in China. Australas Plant Pathol 40:246-259

Lo S-CC, Hipskind JD, Nicholson RL (1999) cDNA Cloning of a sorghum pathogenesis-related protein (PR-10) and differential expression of defense-related genes following inoculation with Cochliobolus heterostrophus or Colletotrichum sublineolum. Mol Plant Microbe Interact 12:479-489

Louie R, Knoke JK, Findley WR (1990) Elite maize germplasm: reactions to maize dwarf mosaic and maize chlorotic dwarf viruses. Crop Sci 30:1210-1215

Luo ZW, He F, Fan HY, Wang XH, Hua M, Hu FC, Li XH, Liu ZX, Yu NT (2011) First report of leaf spot disease caused by Exserohilum rostratum on pineapple in Hainan province, China. Plant Dis 96:458

Machado AR, Pinho DB, Soares DJ, Gomes AM, Pereira OL (2019) Bayesian analyses of five gene regions reveal a new phylogenetic species of Macrophomina associated with charcoal rot on oilseed crops in Brazil. Eur J Plant Pathol 153:89-100

Mahmad Toher AS, Mior Ahmad ZA, Wong MY (2015) First report of Exserohilum rostratum as pathogen of rice brown spot in Malaysia. Plant Dis 100:226

Manamgoda D (2015) A taxonomic and phylogenetic re-appraisal of the genus Curvularia (Pleosporaceae): human and plant pathogens. Phytotaxa 212:175-198

Manamgoda DS, Rossman AY, Castlebury LA, Crous PW, Madrid H, Chukeatirote E, Hyde KD (2014) The genus Bipolaris. Stud Mycol 79:221-288

Marin-Felix Y, Hernandez-Retrepo M, Crous P (2020) Multi-locus phylogeny of the genus Curvularia and description of ten new species. Mycol Prog 19:559-588

Mathur K, Thakur RP, Rao VP, Jadone K, Rathore S, Velazhahan R (2011) Pathogenic variabilityu in Exserohium turcicum and resistance to leaf blight in sorghum. Indian Phytopathol 64:32-36

Massion CL, Lindow SE (1986) Effects of Sphacelotheca holci infection on morphology and competitiveness of Johnsongrass (Sorghum halepense). Weed Sci 34:883-888 
McGee DC (1992) Soybean Diseases: A Reference Source for Seed Technologists. St Paul, MN: American Phytopathological Society. $151 \mathrm{p}$

McKern NM, Whittaker LA, Strike PM, Ford RE, Jensen SG, Shukla DD (1990) Coat protein properties indicate that maize dwarf mosaic virus-KS1 is a strain of Johnsongrass mosaic virus. Phytopathology 80:907-912

McWhorter CG (1971) Introduction and spread of Johnsongrass in the United States. Weed Sci 19:496-500

McWhorter CG, Hartwig EE (1972) Competition of Johnsongrass and cocklebur with six soybean varieties. Weed Sci 20:56-59

Meneses PR, Farias CRJd, Caniela ARdA, Schwanck AA, Deibler AN, Funck GD, Del Ponte EM (2014) Regional and varietal differences in prevalence and incidence levels of Bipolaris species in Brazilian rice seedlots. Trop Plant Pathol 39:349-356

Mengistu H (1982) Diseases of sorghum at some locations in Ethiopia. Ethiopian J Agric Sci 4:45-53

Meredith DS (1963) Some graminicolous fungi associated with spotting of banana leaves in Jamaica. Ann Appl Biol 51:371-378

Mikulas J, Sule S (1979) Bacterial leaf spot of Johnson grass caused by Pseudomonas syringae. Acta Phytopathol Acad Sci Hung 14:83-87

Millhollon R (2000) Loose kernel smut for biocontrol of Sorghum halepense in Saccharum sp. hybrids. Weed Sci 48:645-652

Mitchell JK, Njalamimba-Bertsch M, Bradford NR, Birdsong JA (2003) Development of a submerged-liquid sporulation medium for the Johnsongrass bioherbicide Gloeocercospora sorghi. J Ind Microbiol Biot 30:599-605

Moghaddam PF, Pataky JK (1994) Reactions of isolates from matings of races 1 and $23 \mathrm{~N}$ of Exserohilum turcicum. Plant Dis 78:767-771

Mohammadi MR, Koohi-Habibi M, Mosahebi G, Hajieghrari B (2006) Identification of prevalent potyvirus on maize and johnsongrass in corn fields of Tehran province of Iran and a study on some of its properties. Commun Agric Appl Biol Sci 71:1311-1319

Momtaz MS, Shamsi S, Dey T (2019) Association of Bipolaris and Drechslera species with Bipolaris leaf blight (BPLB) infected wheat leaves. J Bangladesh Acad Sci 43:11-16

Mostafavi FS, Sabbagh SK, Yamchi A, Nasrollanejad S, Panjehkeh N (2019) Differential molecular response of maize and Johnson grass against maize dwarf mosaic virus and bermuda grass southern mosaic virus. Acta Virol 63:70-79

Nagel JH, Wingfield MJ, Slippers, B. (2018) Evolution of the mating types and mating strategies in prominent genera in the Botryosphaeriaceae. Fungal Genet Biol 114:24-33

Odvody G, Isaskeit T (1997) Sorghum ergot in the United States-public sector response. Pages 68-75 in Casela C, Dahlberg J, eds. Global Conference on Ergot of Sorghum. Sete Lagaos, Brazil: EMBRAPA and INTSORMIL

Odvody G, Montes N, Frederickson ED, Narro-Sánchez J (2002) Detection of sclerotia of Claviceps africana in the western hemisphere. Pages 129-130 in Leslie JF, ed. Sorghum and Millets Diseases. 1st ed. Ames: Iowa State Press

Odvody G, Rosenow DT, Black MC (2006) First report of Ramulispora sorghicola in the United States causing oval leaf spot on Johnsongrass and sorghum in Texas. Plant Dis 90:108

Ouedraogo I, Wonni I, Sereme D, Kabore K (2016) Survey of fungal seed-borne diseases of rice in Burkina Faso. Int J Agric Innov Res 5:476-480

Pant SK, Kumar P, Chauhan VS (2000) Effect of turcicum leaf blight on photosynthesis in maize. Indian Phytopathol 54:251-252

Paterson AH, Kong W, Johnston RM, Nabukalu P, Wu G, Poehlman WL, Goff VH, Isaacs K, Lee T-H, Guo H, Zhang D, Sezen UU, Kennedy M, Bauer D, Feltus FA, et al. (2020) The evolution of an invasive plant, Sorghum halepense L. ('Johnsongrass'). Front Genet 11. https://www.frontiersin.org/ article/10.3389/fgene.2020.00317. Accessed: August 1, 2020

Peng C, Ge TT, He XL, Huang YH, Xu ZL, Zhang DY, Shao HB, Guo SW (2016) Process of Bipolaris sorghicola invasion of host cells. Genet Mol Res $15: 15016781$

Pratt RG (2006) Johnsongrass, yellow foxtail, and broadleaf signalgrass as new hosts for six species of Bipolaris, Curvularia, and Exserohilum pathogenic to bermudagrass. Plant Dis 90:528

Prom LK, Ahn E, Isakeit T, Magill C (2019) GWAS analysis of sorghum association panel lines identifies SNPs associated with disease response to Texas isolates of Colletotrichum sublineola. Theor Appl Genet 132:1389-1396
Prom LK, Isakeit T, Odvody GN, Rush CM, Kaufman HW, Montes N (2005) Survival of Claviceps africana within sorghum panicles at several Texas locations. Plant Dis 89:39-43

Prom LK, Magill C, Droleskey R (2017a) Aggressiveness of loose kernel smut isolate from Johnson grass on sorghum line BTx643. J Agric 3:94-96

Prom LK, Radwan, G, Perumal R, Cuevas H, Katile SO, Isakeit T, Magill C (2017b) Grain biodeterioration of sorghum converted lines inoculated with a mixture of Fusarium thapsinum and Curvularia lunata. Plant Pathol J 16:19-24

Redinbaugh MG, Stewart LR (2018) Maize lethal necrosis: an emerging, synergistic viral disease. Annu Rev Virol 5:301-322

Rodriguez CM, Madden LV, Nault LR, Louie R (1993) Spread of maize chlorotic dwarf virus from infected corn and Johnsongrass by Graminella nigrifrons. Plant Dis 77:55-60

Ruhl G, Wise K, Creswell T, Leonberger A, Speers C (2009) First report of Goss's bacterial wilt and leaf blight on corn caused by Clavibacter michiganensis subsp. nebraskensis in Indiana. Plant Dis 93:841

Rybicki EPA (2015) Top ten list for economically important plant viruses. Arch Virol 160:17-20

Sarr MP, Ndiaye MB, Groenewald JZ, Crous PW (2014) Genetic diversity in Macrophomina phaseolina, the causal agent of charcoal rot. Phytopathol Mediterr 53:250-268

Schwinning S, Meckel H, Reichmann LG, Polley HW, Fay PA (2017) Accelerated development in Johnsongrass seedlings (Sorghum halepense) suppresses the growth of native grasses through size-asymmetric competition. PLoS ONE 12:e0176042

Sezen UU, Barney JN, Atwater DZ, Pederson GA, Pederson JF, Chandler JM, Cox TS, Cox S, Dotray P, Kopec D, Smith SE, Schroeder J, Wright SD, Jiao Y, Kong W, et al. (2016) Multi-phase US spread and habitat switching of a post-Columbian invasive, Sorghum halepense. PLoS ONE 11: e0164584

Shapland EB, Daane KM, Yokota GY, Wistrom C, Connell JH, Duncan RA, Viveros MA (2006) Ground vegetation survey for Xylella fastidiosa in California almond orchards. Plant Dis 90:905-909

Shephard (1965) Properties of a mpoai virus of corn and Johnson grass and its relation to the sugarcane mosaic virus. Phytopathology 55: $1250-1256$

Sherriff C, Whelan MJ, Arnold GM, Bailey JA (1995) rDNA sequence analysis confirms the distinction between Colletotrichum graminicola and C. sublineolum. Mycol Res 99:475-478

Sifat MSA, Monjil MS (2017) Mycelial growth inhibition of rhizoctonia by indigenous medicinal plant extract. Progress Agric 28:190-197

Soti P, Goolsby JA, Racelis A (2020) Agricultural and environmental weeds of south Texas and their management. Subtrop Agric Environ 71:1-11

Stewart LR, Teplier R, Todd JC, Jones MW, Cassone BJ, Wijeratne S, Wijeratne A, Redinbaugh MG (2014) Viruses in maize and Johnsongrass in southern Ohio. Phytopathology 104:1360-1369

Stewart LR, Willie K, Wijeratne S, Redinbaugh MG, Massawe D, Niblett CL, Kiggundu A, Asiimwe T (2017) Johnsongrass mosaic virus contributes to maize lethal necrosis in East Africa. Plant Dis 101:1455-1462

Sturrock CJ, Woodhall J, Brown M, Walker C, Mooney SJ, Ray RV (2015) Effects of damping-off caused by Rhizoctonia solani anastomosis group 21 on roots of wheat and oil seed rape quantified using X-ray computed tomography and real-time PCR. Front Plant Sci 6:461

Tahvonen R, Hollo J, Hannukkala A, Kurppa A (1984) Rhizoctonia solani damping-off on spring turnip rape and spring rape (Brassica spp.) in Finland. J Agric Sci Finland 56:143-154

Tong L, LongZhou L, Jumei H, Lan J (2016) First report of Curvularia lunata causing leaf spots on sweet sorghum (Sorghum bicolor) in China. Disease Notes 100:652

Tumber KP, Alston JM, Fuller KB (2014) Pierce's disease costs California \$104 million per year. Calif Agric (Berkeley) 68:20-29

Turner WF, Pollard HN (1959) Life Histories and Behavior of Five Insect Vectors of Phony Peach Disease. Technical Bulletin 1188. Washington, DC: U.S. Department of Agriculture. $28 \mathrm{p}$

Vaillancourt LJ, Hanau RM (1992) Genetic and morphological comparisons of Glomerella (Colletotrichum) isolates from maize and from sorghum. Exp Mycol 16:219-229 
Velasquez-Valle R, Narro-Sanchez J, Mora-Nolasco R, Odvody GN (1998) Spread of ergot of sorghum (Claviceps africana) in central Mexico. Plant Dis 82:447

Viswanathan R, Balamuralikrishnan M (2005) Impact of mosaic infection on growth and yield of sugarcane. Sugar Technol 7:61-65

Voorhees R (1934) Sclerotial rot of corn caused by Rhizoctonia zeae n. sp. Phytopathology 24:1290-1303

Warwick SI, Black LD (1983) The biology of Canadian weeds.: 61. Sorghum halepense (L.) Pers. Can J Plant Sci 63:997-1014

Weaver DJ, BC Raju, JM Wells, SK Lowe (1980) Occurrence in Johnsongrass of rickettsia-like bacteria related to the phony peach disease organism. Plant Dis 64:485-487

Weems JD, Bradley CA (2017) Exserohilum turcicum race population distribution in the north central United States. Plant Dis 102:292-299

Wijayasekara D, Ali A (2017) First report of maize dwarf mosaic virus in Johnsongrass in Oklahoma. Plant Dis 101:850

Williams LE, Findley WR, Dollinger EJ, Blair BD, Spilker OW (1966) Corn Virus Research in Ohio in 1965. Research Circular 145. Wooster: Ohio Agricultural Research and Development Center

Wisler GC, Norris RF (2005) Interactions between weeds and cultivated plants as related to management of plant pathogens. Weed Sci 53:914-917
Wistrom C, Purcell AH (2005) The fate of Xylella fastidiosa in vineyard weeds and other alternate hosts in California. Plant Dis 89:994-999

Xavier KV, Mizubuti ESG, Queiroz MV, Chopra S, Vaillancourt L (2018) Genotypic and pathogenic diversity of Colletotrichum sublineola isolates from sorghum (Sorghum bicolor) and Johnsongrass (S. halepense) in the southeastern United States. Plant Dis 102:2341-2351

Yang XB, Navi SS (2005) First report of charcoal rot epidemics caused by Macrophomina phaseolina in soybean in Iowa. Plant Dis 89:526

Yu T, Wang Z, Jin X, Liu X, Kan S (2014) Analysis of gene expression profiles in response to Sporisorium reilianum $\mathrm{f}$. sp. zeae in maize (Zea mays L.). Electron J Biotechnol 17:230-237

Zehhar G, Touhami AO, Douira A (2008) First report of Bipolaris cynodontis on Oryza sativa in Morocco. Phytopathol Mediterr 47:73-76

Zhang X, Fernandes SB, Kaiser C, Adhikari P, Brown PJ, Mideros SX, Jamann TM (2020) Conserved defense responses between maize and sorghum to Exserohilum turcicum. BMC Plant Biology 20:67

Zhu M, Chen Y, Ding XS, Webb SL, Zhou T, Nelson RS, Fan Z (2014) Maize elongin $\mathrm{C}$ interacts with the viral genome linked protein, $\mathrm{VPg}$, of sugarcane mosaic virus and facilitates virus infection. New Phytol 203:1291-1304 